\title{
New Record of Leidynema appendiculata (Leidy, 1850) Chitwood, 1932. (Oxyuroidea: Thelastomatidae) from the Cockroaches Blatta orientalis (Dictyopetra: Blattidae) from Kashmir
}

\author{
Rehana R, Bhagat RC, Fayaz A Rukhsana and Tanveer A Sofi ${ }^{\star}$
}

Department of Zoology, University of Kashmir, Srinagar, Jammu and Kashmir, India

\begin{abstract}
During the present study, for the first time Nematode parasites were from the colon region of the intestine of Blatta orientalis from Srinagar. On close examination, they were found to resemble to those of Leidynema appendiculate in all their morphological and biological features. Both male and female specimens were recovered but male specimens were lesser in comparison to females. Measurements and camera lucida drawings are also given.
\end{abstract}

\section{Keywords: Cockroach; Nematode; Measurements; Srinagar}

\section{Introduction}

Insect parasitic nematodes are small and round worms that complete part of their life-cycle in insects. Several species of these nematodes can kill insects in this process and are of considerable interest because of their potential being developed and marketed as biological control agents of pest insects. Parasitic nematodes of Kashmir valley offer an ideal environment for the survival of various kinds of insect's species to unique geographical position of temperate climate [1,2]. It is home for representative of almost all phyla situated in the subtropical north temperate region of Asia.

Thousands of species of insect parasitic nematodes not only attack the general insects form, belonging to different orders but also the insect pests of agricultural, veterinary, medical and forestry importance. Potential for use of entomophilic nematodes as self perpetuating biological control agents lies in areas where chemical pesticides are too expensive, not practical or most noxious to human and environment [3].

\section{Materials and Methods}

The cockroaches for the present study were collected at nighe with the help of forceps from toilet, main holes bathroom from different localities of Srinagar, and were then dissected with the help of scissors, forceps and needles and the alimentary tract was drawn out intact by grasping the head and thorax and gently pulling apart. The intestine was then slit lengthwise with fine needles and placed flat on a slide. Although the nematode parasites were best studied alive, distilled water and normal salt solution were found to be the best media to observe live nematode Parasites. Nematodes were picked out of this suspension under the low magnification of a Stereoscopic microscope. Slivers of bamboo and fine tipped brushes were used in the present study for handling and picking of nematodes for its easy availability and handling.

After thorough washing of the parasites in normal saline were fixed in either AFA or in Sizzling hot 70\% alcohol. Subsequently they were cleared in glycerin or in lactophenol. Their temporary mounts were made in glycerin. Nematodes were arranged in the centre of a drop of mounting fluid separated from each other and rested on the glass slide i.e., not floating in the mountant [4]. All diagrams were made with the help of camera lucida and measurements were taken with the aid of oculometer in $\mathrm{mm}$.

\section{Key to the Families of Superfamily Oxyuroidea}

1. Corpus of oesophagus not extremely short; male with one or zero spicules - Corpus of oesophagus extremely short and thick; male with two or zero spicules - Atractidae.

2. External circle of 4-double cephalic papillae - External circle of 8-cephalic papillae - Thelastomatidae.

3. Adults usually in hindgut of vertebrates chiefly amphibians, reptiles and mammala - Oxyuridae.

Adults found in gut of millipedes - Rhingonematidae

\section{Diagnostic Characters of the Family Thelastomatidae}

The thalastomatid, parasites of insects and myriapods, throughout the literature and descriptions of between 60 and 70 species have been provided but usually not much other information is available. However, studies by Dobrovolny and Ackert [5] and other indicate that most of these species probably have the same type of the life-cycle which is comparatively simple. Eggs pass out of the host with feces. Eggs do not hatch in the intestine to re-infect the same host but must first undergo some development on the outside to reach an infective stage. The various arthropod hosts acquire their parasites by swallowing these infective eggs.

Mouth of female surrounded by eight sub median papillae or labiopapillae. Amphids represented externally by circular or oval openings; esophagus consisting of an anterior corpus, which may or may not be modified; a more or less distinct isthmus and a posterior valvular bulb. Females with one or more ovaries. Male with single testis, a single spicule or none, and one to five pairs of caudal papillae $[6,7]$.

*Corresponding author: Tanveer A Sofi, Department of Zoology, University of Kashmir, Srinagar-190 006, Jammu and Kashmir, India, Tel: +919797127214; E-mail: stanveer96@gmail.com

Received October 07, 2016; Accepted November 07, 2016; Published November 11, 2016

Citation: Rehana R, Bhagat RC, Rukhsana AF, Sofi TA (2016) New Record of Leidynema appendiculata (Leidy, 1850) Chitwood, 1932. (Oxyuroidea: Thelastomatidae) from the Cockroaches Blatta orientalis (Dictyopetra: Blattidae) from Kashmir. J Vet Sci Technol 7: 403. doi: 10.4172/2157-7579.1000403

Copyright: $\odot 2016$ Rehana R, et al. This is an open-access article distributed under the terms of the Creative Commons Attribution License, which permits unrestricted use, distribution, and reproduction in any medium, provided the original author and source are credited. 
Citation: Rehana R, Bhagat RC, Rukhsana AF, Sofi TA (2016) New Record of Leidynema appendiculata (Leidy, 1850) Chitwood, 1932. (Oxyuroidea: Thelastomatidae) from the Cockroaches Blatta orientalis (Dictyopetra: Blattidae) from Kashmir. J Vet Sci Technol 7: 403. doi: 10.4172/21577579.1000403

Page 2 of 6

\section{Key to the Genera of Family Thelastomatidae}

1. Vulva posterior to base of esophagus - Vulva anterior to base of esophagus - 7

2. Esophagus with a pseudo bulb - 3 - Esophagus without a pseudo bulb - Blattellicola

3. Vulva in anterior part of body - Hammerschmidtiella - Vulva about middle or posterior to middle of body

4. Anterior and posterior parts of corpus not distinctly set off, the whole corpus forming a pear-shaped pseudo bulb - Aorurus Anterior and posterior parts of corpus distinctly setoff

5. Corpus distinctly enlarged in form of a sub spherical swelling at base of buccal cavity - Blatophila

6. Corpus not distinctly enlarged in form of a sub spherical swelling at the base of buccal cavity

7. Corpus terminated by sub-cylindrical swelling - Leidynema

8. Corpus terminated by sub-spherical swelling - Leidynemella

9. Tail of female short and conical

10. Tail of female long and filiform - Linstowiella

11. Female esophagus long and narrow, forming about $1 / 4$ of body length - Protrelloides

12. Female esophagus not as long as narrow - Protrellus.

\section{Diagnostic Characters of the Genus Leidynema}

Mouth surrounded by very large sub median labiopapillae, amphids or lateral organs appearing externally as small circular openings. Esophagus of female consisting of an anterior part which is subdivided into cylindrical parts of which the posterior is somewhat larger in diameter than the anterior, a distinct isthmus, and a valvular bulb. Excretory pore posterior to base of esophagus. Intestine may or may not be enlarged anteriorly to form a cardia; a posteriorly directed caecum may or may not be present; the intestine may have a loop in the posterior part of the body. Vulva near middle of body; amphidelphic [8-10]. Eggs ellipsoidal. Esophagus of male without distinct posterior swelling in anterior part of esophagus. Tail of female attenuated or filiform. Tail of male short, rounded, filiform. One pair of large preanal caudal papillae, two pairs of postanal papillae. One spicule.

\section{Leidynema appendiculata (Leidy, 1850) Chitwood, 1932}

\section{Host: Blatta orientalis Linn.}

Site of infection: Large intestine

\section{Location: Srinagar}

Twenty-eight female and two male nematode parasites from ten Cockroaches (Blatta orientalis) from Srinagar, were recovered. It favored more anterior position and was more restricted in its distribution in the colon and was found to be a lumen dweller. A brief description of the parasite is given as under.

\section{Description}

\section{Female}

$2.14 \mathrm{~mm}$ long by $0.27 \mathrm{~mm}(270 \mu)$ wide. Cuticle closely annulated throughout the length of body. Lateral alae prominent, each ala terminating posteriorly in a spine-like projection. Buccal capsule is $0.02 \mathrm{~mm}$ long and $0.01 \mathrm{~mm}$ wide. Esophagus $0.43 \mathrm{~mm}(430 \mu)$ long consisting of an anterior corpus 0.32 $\mathrm{mm}(320 \mu)$ long, subdivided into an anterior part $0.17 \mathrm{~mm}(170 \mu)$ long by $0.035 \mathrm{~mm}(35 \mu)$ wide and a posterior pseudo bulb $0.14 \mathrm{~mm}$ $(140 \mu)$ long by $0.06 \mathrm{~mm}(60 \mu)$ wide, an isthmus $0.03 \mathrm{~mm}(30 \mu)$ long by $0.04 \mathrm{~mm}(40 \mu)$ wide, set off distinctly from the anterior cylindrical pseudo bulb, and a posterior valvular bulb $0.09 \mathrm{~mm}(90 \mu)$ long by 0.12 $\mathrm{mm}(120 \mu)$ wide. Nerve ring $0.16 \mathrm{~mm}(160 \mu)$ from the anterior end of body; Anterior part of intestine greatly enlarged, provided with a posteriorly directed intestinal caecum or diverticulum (Figures 1-3; Pmgs 1-4; Table 1) posterior part of intestine forming a loop in mature specimens. Anus $0.36 \mathrm{~mm}$ from the tip of the tail. Tail filiform. Vulva slightly posterior to middle of body, $1.12 \mathrm{~mm}$ from anterior end of the body. Ovaries two; amphidelphic. Eggs oval, elongate and flattened slightly on one side, $94 \mu$ long by $40 \mu$ Wide.

\section{Male}

$0.088 \mathrm{~mm} 880 \mu$ long by $0.055 \mathrm{~mm}(55 \mu)$ wide; cuticle striated, striations prominent near the anterior end, $0.003 \mathrm{~mm}(3.33 \mu)$ apart. Buccal capsule $0.003 \mathrm{~mm}(3.33 \mu)$ by $0.001 \mathrm{~mm}(1.66 \mu)$. Esophagus $0.14 \mathrm{~mm}(140 \mu)$ long; anterior part $0.105 \mathrm{~mm}(105 \mu)$ long by $0.01 \mathrm{~mm}$ $(10 \mu)$ wide; isthmus $10.001 \mathrm{~mm}(17.5 \mu)$ long by $0.01 \mathrm{~mm}(10 \mu)$ wide, not distinctly set off; bulb $0.025 \mathrm{~mm}(25 \mu)$ long by $0.02(20 \mu)$ wide. Nerve ring $0.09 \mathrm{~mm}(90 \mu)$ from anterior end of body. Intestine simple without a diverticulum or a loop, anus $0.01 \mathrm{~mm}(10 \mu)$ from posterior end of body. Tail much attenuated and very small, provided with one pair of large sub-ventral preanal papillae, one pair of sub-ventral post anal papillar, and one pair of small, sub-dorsal papillae. One spicule $0.026 \mathrm{~mm}(26.666 \mu)$ long (Figures 4-6; Pmgs 5-12; Table 2) [11].

\section{Remarks}

The genus Leidynema was proposed by Schwenk in Travassos, 1929 to accommodate Oxyuris blattae oreintalis

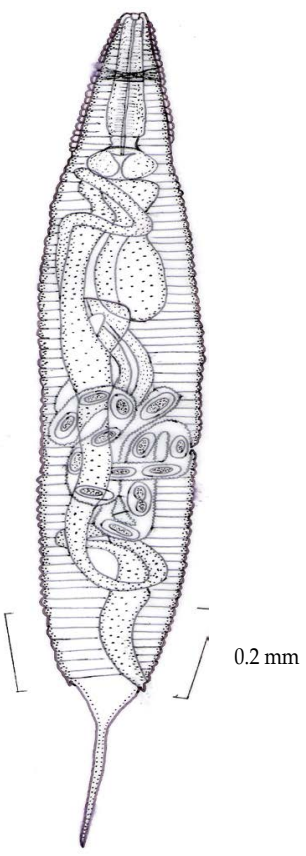

Figure 1: Leidynema appendiculata (Female, Entire Specimen). 
Citation: Rehana R, Bhagat RC, Rukhsana AF, Sofi TA (2016) New Record of Leidynema appendiculata (Leidy, 1850) Chitwood, 1932. (Oxyuroidea: Thelastomatidae) from the Cockroaches Blatta orientalis (Dictyopetra: Blattidae) from Kashmir. J Vet Sci Technol 7: 403. doi: 10.4172/21577579.1000403

Page 3 of 6

\begin{tabular}{|c|c|c|c|c|}
\hline \multicolumn{2}{|c|}{$\begin{array}{l}\text { Measurements } \\
\text { (a) }\end{array}$} & (Leidy and Chitwood) $[3,8]$ & Dobrovolony and Ackert [5] & Present specimens \\
\hline \multicolumn{2}{|c|}{ Length } & $1.9-4.025 \mathrm{~mm}$ & $2.27-4.025 \mathrm{~mm}$ & $2.14 \mathrm{~mm}$ \\
\hline \multicolumn{2}{|c|}{ Width } & $140-350 \mu$ & $0.238-0.35 \mathrm{~mm}$ & $0.27 \mathrm{~mm}(270 \mu)$ \\
\hline \multirow{2}{*}{ Buccal capsule } & Length & - & - & $0.02 \mathrm{~mm}$ \\
\hline & Width & - & - & $0.01 \mathrm{~mm}$ \\
\hline \multicolumn{2}{|c|}{$\begin{array}{c}\text { Nerve ring } \\
\text { From anterior end of body }\end{array}$} & $120-195 \mu$ & $0.135-0.195 \mathrm{~mm}$ & $0.16 \mathrm{~mm}(160 \mu)$ \\
\hline \multicolumn{2}{|c|}{ Esophagus } & $396-497 \mu$ & $0.435-0.497 \mathrm{~mm}$ & $0.43 \mathrm{~mm}(430 \mu)$ \\
\hline \multicolumn{2}{|c|}{ Anterior corpus length } & $290-330 \mu$ & - & $0.32 \mathrm{~mm}(320 \mu)$ \\
\hline \multirow{2}{*}{ Anterior part } & Length & $144-180 \mu$ & - & $0.17 \mathrm{~mm}(170 \mu)$ \\
\hline & Width & $30-36 \mu$ & $0.045-0.085 \mathrm{~mm}$ & $0.035 \mathrm{~mm}(35 \mu)$ \\
\hline \multirow{2}{*}{ Posterior Pseudo bulb } & Length & $140-148 \mu$ & - & $0.14 \mathrm{~mm}(140 \mu)$ \\
\hline & Width & $30-36 \mu$ & - & $0.06 \mathrm{~mm}(60 \mu)$ \\
\hline \multirow{2}{*}{ Isthmus } & Length & $16-45 \mu$ & $0.021-0.045 \mathrm{~mm}$ & $0.03 \mathrm{~mm}(30 \mu)$ \\
\hline & Width & $35-40 \mu$ & $0.035-0.04 \mathrm{~mm}$ & $0.04 \mathrm{~mm}(40 \mu)$ \\
\hline \multirow{2}{*}{ Valvular Bulb } & Length & $90-106 \mu$ & $0.09-0.106 \mathrm{~mm}$ & $0.09 \mathrm{~mm}(90 \mu)$ \\
\hline & Width & $100-148 \mu$ & $0.1-0.148 \mathrm{~mm}$ & $0.12 \mathrm{~mm}(120 \mu)$ \\
\hline \multicolumn{2}{|c|}{ Anus from tip of tail } & $420-825 \mu$ & $0.42-0.825 \mathrm{~mm}$ & $0.44 \mathrm{~mm}(440 \mu)$ \\
\hline \multicolumn{2}{|c|}{ Vulva from ant. end } & $1.05-1.985 \mathrm{~mm}$ & $1.05-1.985 \mathrm{~mm}$ & $1.12 \mathrm{~mm}$ \\
\hline \multirow{2}{*}{ Cuticular Striations } & At ant. end. & - & - & $0.02 \mathrm{~mm}$ \\
\hline & at post. end & - & - & $0.04 \mathrm{~mm}$ \\
\hline \multirow{2}{*}{ Eggs } & Length & $100-112 \mu$ & $0.106-0.112 \mathrm{~mm}$ & $94 \mu$ \\
\hline & Width & $45-53 \mu$ & $0.045-0.048 \mathrm{~mm}$ & $40 \mu$ \\
\hline
\end{tabular}

Table 1: Measurements of Leidynema appendiculata (Female).

\begin{tabular}{|c|c|c|c|c|}
\hline \multicolumn{2}{|c|}{ Measurements } & (Leidy and Chitwood) $[3,8]$ & Dobrovolony and Ackert [5] & Present specimen \\
\hline \multicolumn{2}{|c|}{ Length } & $0.525-0.850 \mathrm{~mm}(525-850 \mu)$ & $0.525-0.850 \mathrm{~mm}$ & $0.88 \mathrm{~mm}(880 \mu)$ \\
\hline \multicolumn{2}{|c|}{ Width } & $0.045-0.087 \mathrm{~mm}(45-87 \mu)$ & $0.045-0.087 \mathrm{~mm}$ & $0.045 \mathrm{~mm}(45 \mu)$ \\
\hline \multirow{2}{*}{ Buccal capsule } & Length & - & - & $0.0033 \mathrm{~mm}(3.33 \mu)$ \\
\hline & Width & - & - & $0.0016 \mathrm{~mm}(1.66 \mu)$ \\
\hline \multicolumn{2}{|c|}{ Nerve ring from ant end of body } & $0.075-0.155 \mathrm{~mm}(75-155 \mu)$ & $0.075-0.105 \mathrm{~mm}$ & $0.09 \mathrm{~mm}(90 \mu)$ \\
\hline \multicolumn{2}{|c|}{ esophagus } & $0.133-0.185 \mathrm{~mm}(133-216 \mu)$ & $0.133-0.185 \mathrm{~mm}$ & $0.17 \mathrm{~mm}(170 \mu)$ \\
\hline \multirow{2}{*}{ Anterior part } & Length & $80-166 \mu$ & $0.08-0.125 \mathrm{~mm}$ & $0.105 \mathrm{~mm}(105 \mu)$ \\
\hline & Width & $8-20 \mu$ & $0.015-0.02 \mathrm{~mm}$ & $0.01 \mathrm{~mm}(10 \mu)$ \\
\hline \multirow{2}{*}{ Isthmus } & Length & $17-20 \mu$ & $0.017-0.02 \mathrm{~mm}$ & $0.00175 \mathrm{~mm}(17.5 \mu)$ \\
\hline & Width & $0.009-0.12 \mathrm{~mm}(9-12 \mu)$ & $0.009-0.12 \mathrm{~mm}$ & $0.01 \mathrm{~mm}(10 \mu)$ \\
\hline \multirow{2}{*}{ Bulb } & Length & $0.034-0.04 \mathrm{~mm}(34-40 \mu)$ & $0.034-0.04 \mathrm{~mm}$ & $0.025 \mathrm{~mm}(25 \mu)$ \\
\hline & Width & $0.020-0.036 \mathrm{~mm}(20-36 \mu)$ & $0.027-0.036 \mathrm{~mm}$ & $0.02 \mathrm{~mm}(20 \mu)$ \\
\hline \multicolumn{2}{|c|}{ Anus from post end } & $0.01-0.20 \mathrm{~mm}(10-20 \mu)$ & $0.01-0.15 \mathrm{~mm}$ & $0.01 \mathrm{~mm}(10 \mu)$ \\
\hline \multicolumn{2}{|c|}{ Cuticular striations (length at anterior end) } & $0.003 \mathrm{~mm}(3 \mu)$ & $0.003 \mathrm{~mm}$ & $0.0033 \mathrm{~mm}(3.33 \mu)$ \\
\hline \multicolumn{2}{|c|}{ Spicule } & $0.026-0.035 \mathrm{~mm}(26-35 \mu)$ & $0.026-0.035 \mathrm{~mm}$ & $0.0266666 \mathrm{~mm}(26.6666 \mu)$ \\
\hline
\end{tabular}

Table 2: Measurements of Leidynema appendiculata (Male).

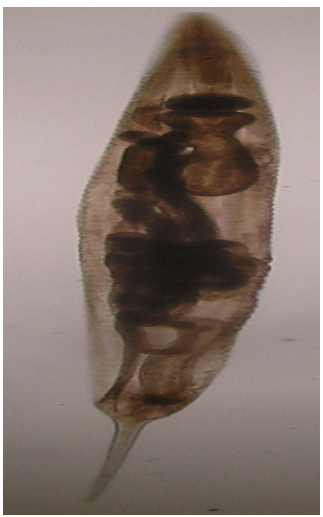

Pmg 1: Leidynema appendiculata (Female, Entire Specimen) 40X.

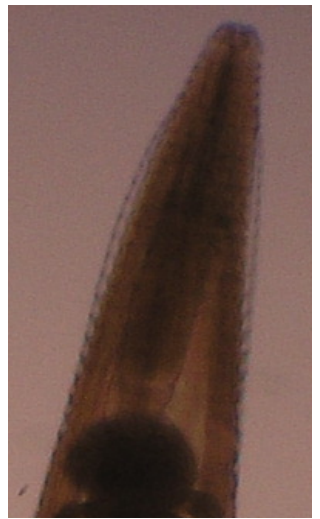

Pmg 2: Anterior end showing Esophagus 100X. 
Citation: Rehana R, Bhagat RC, Rukhsana AF, Sofi TA (2016) New Record of Leidynema appendiculata (Leidy, 1850) Chitwood, 1932. (Oxyuroidea: Thelastomatidae) from the Cockroaches Blatta orientalis (Dictyopetra: Blattidae) from Kashmir. J Vet Sci Technol 7: 403. doi: 10.4172/21577579.1000403

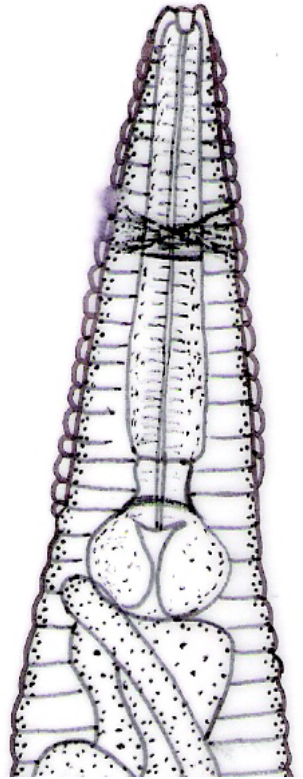

Figure 2: Anterior end (Enlarged view).

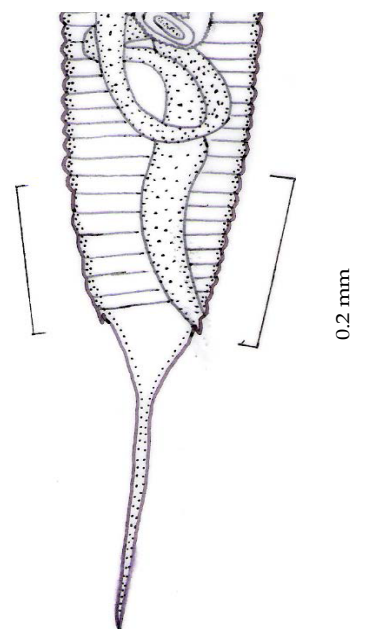

Figure 3: Posterior end (Enlarged view)

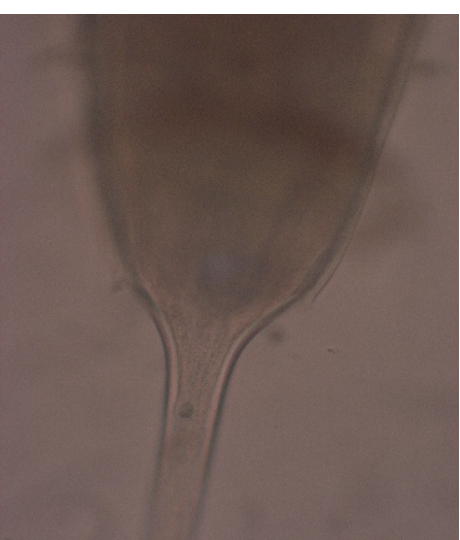

Pmg 3: Posterior end with spine like projections 100X.

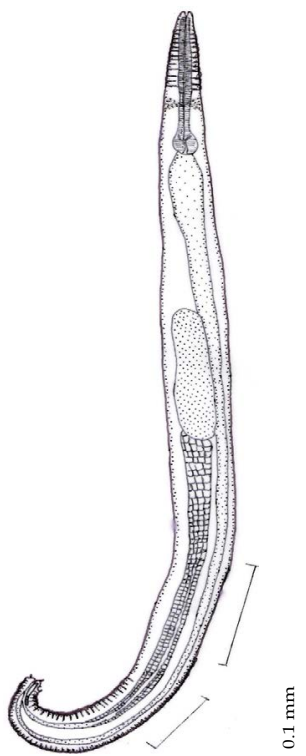

Figure 4: Leidynema appendiculata (Male, Entire Specimen).

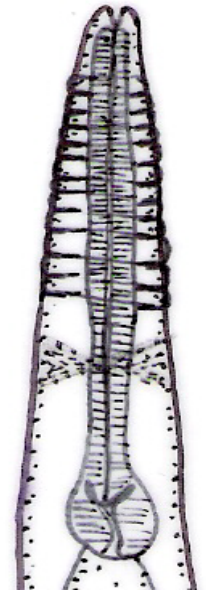

Figure 5: Anterior end (Enlarged view)

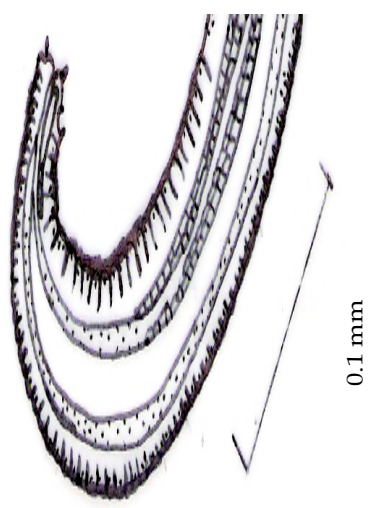

Figure 6: Posterior end (Enlarged view) 
Citation: Rehana R, Bhagat RC, Rukhsana AF, Sofi TA (2016) New Record of Leidynema appendiculata (Leidy, 1850) Chitwood, 1932. (Oxyuroidea: Thelastomatidae) from the Cockroaches Blatta orientalis (Dictyopetra: Blattidae) from Kashmir. J Vet Sci Technol 7: 403. doi: 10.4172/21577579.1000403

Ham., 1847. From Hammer Schmidt's original description and figures of this worm it becomes apparent that he had only re described and redrawn his previously described $O$. diesingi, and the latter has been placed in the genus Aorurus by Travassos 1929. Apparently, Schwenk agrees with Leidy (1851) who cites O. blattae oreintalis as being the same species as his Thelastomum appendiculatum. Butschli (1871), Galeb (1878) and Magalhaes (1900) have followed Leidy in this matter. O. blattae oreintalis now being regarded as a synonym of Hammer Schmidtiella diesingi (O. diesingi), the type species of the

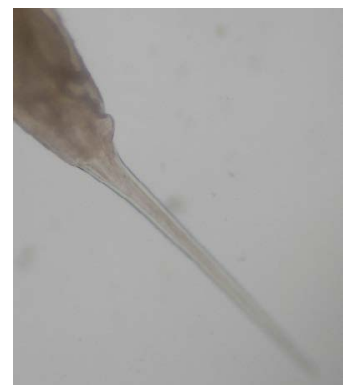

Pmg 4: Tail region showing Anus 100X.

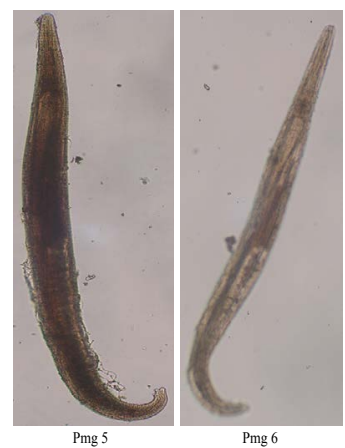

Pmg 5 and 6: Leidynema appendiculata (Male, Entire Specimen) 100X.

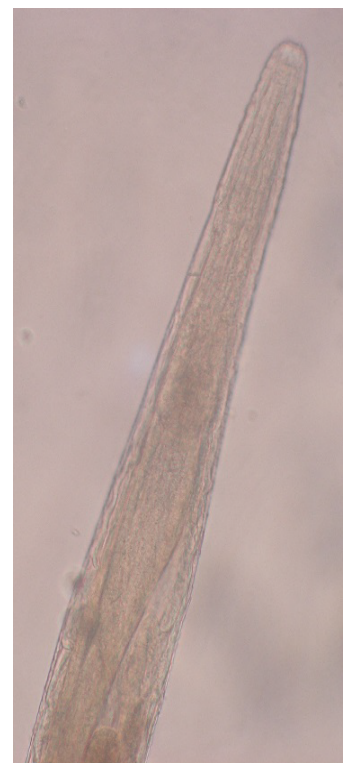

Pmg 7: Anterior esophageal region.

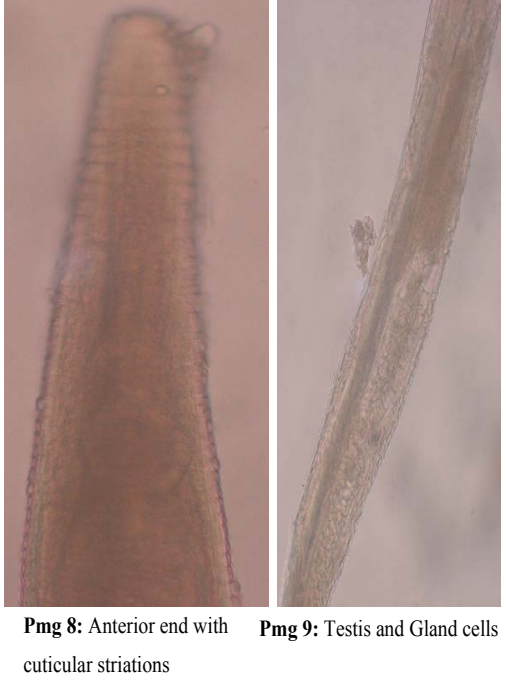

Pmg 8 and 9: Leidynema appendiculata (Male) 100X.
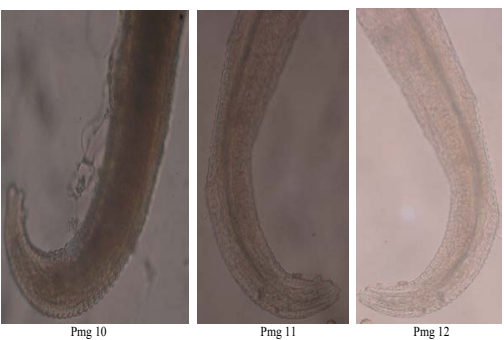

Pmgs 10-12: Leidynema appendiculata [Male] with tail region showing Ana Papillae and Spicule 100X.

genus Leidynema will have the name of L. appendiculatum, this being the original name of the species and meant for the type species of this genus by Schwenk. Chitwood (1932) added two species, L. cranifera and L. delatorrei to this genus and Chitwood and Chitwood, 1933 added a fourth, L. nocalum. Serrano Sanchez 1947 divided the type species, $L$. appendiculatum, into three varieties, $L$. appendiculate var. americana, L. appendiculata var. indiana and L. apendiculata var. hispana.

On comparing the present specimens with the Leidynema appendiculata (Leidy, 1850) Chitwood, 1932 type species of the genus Leidynema Schwenk and by Dobrovolony and Ackert [5] the present specimen is very close to it in all its measurements except for some size differences. The morphological features, like the presence of pseudo and valvular bulb [12] in anterior corpus of females and presence isthmus, presence of filiform tail and oval eggs and presence of one spicule in males confirms its resemblance to L. appendiculata.

From the above discussion, it becomes clear that the present specimens possess all the diagnostic features of the species Leidynema appendiculata (Leidy, 1850) Chitwood, 1932 except for some size variations and locality hence the present specimens are assigned to it. While Kashmir Valley is the new locality record for this species.

\section{References}

1. Butschli $O$ (1871) Untersuchungen liber die beiden Nematoden der Periplaneta (Blatta) orientalis L. Zeitschrift wiss Zool 21: 252-293.

2. Chitwood BG (1932) A synopsis of the nematodes parasitic in insects of the family Blattidae. Z Parasitenkd 5: 14-50. 
Citation: Rehana R, Bhagat RC, Rukhsana AF, Sofi TA (2016) New Record of Leidynema appendiculata (Leidy, 1850) Chitwood, 1932. (Oxyuroidea: Thelastomatidae) from the Cockroaches Blatta orientalis (Dictyopetra: Blattidae) from Kashmir. J Vet Sci Technol 7: 403. doi: 10.4172/21577579.1000403

Page 6 of 6

3. Chitwood BG, Chitwood MB (1933) Nematodes parasitic in Philippine cockroaches. Philippine J Sci 52: 381-393.

4. Magalhaes PD (1900) Notes d'helminthologie bresilienne. Archives de Parasitologie (Paris) 3: 34-69.

5. Dobrovolny CG, Ackert JE (1934) The life history of Leidynema appendiculata (Leidy), a nematode of cockroaches. Parasitol 26: 468-480.

6. Galeb O (1878) Oxyurides parasites des insects. Rev Int Sci 2: 432-434.

7. Hammerschmidt KE (1847) Beschreibung einiger Oxxuris-Arten. Naturwiss Abh Wien 1: 279-288.
8. Leidy J (1850) Description of some nematoid entozoan infesting insects. Proc Acad Nat Sci Philadelphia 5: 100-106.

9. Leidy J (1851) Description of new species of Entosoa. Proc Natl Acad Sc Philadelphia 5: 155-156.

10. Schwenk JM (1926) Fauna pararsitologica dos blattideos do Brasil. Sci Medica 4: 491-504.

11. Serrano Sanchez A (1947) Nematodes parasitos intestinales de los artropodos en Espana. Rev Iberica Parasitologia 7: 279-332.

12. Travassos $L$ (1929) Contribuicao preliminary a systematica dos nematoideos dos arthropodes. Mem Inst Oswaldo Cruz Suppl 5: 19-25. 